\title{
In the Spirit of Quality Student Teachers' English Proficiency and Pedagogical Skills: Teacher Educators and School Principals' Perception
}

\author{
Urip Sulistiyo \\ Jambi University, Faculty of Teacher Training and Education, English Language Education Department,
} Jambi City, Indonesia, usulis2012@gmail.com

\section{Amirul Mukminin}

Jambi University, Graduate School, Educational Management Department, Jambi City, Indonesia, amirul.mukminin@unja.ac.id

\section{Yanto Yanto}

Jambi University, Faculty of Teacher Training and Education, English Language Education Department, Jambi City, Indonesia, yanto7382@yahoo.com

\begin{abstract}
The aim of this research was to document information on English teacher education program at one state-owned university in Jambi, Indonesia in order to better prepare student teachers with sufficient knowledge and skills they need to teach. Information was gathered from school principals' and teacher educators' perceptions on beginner teachers' English proficiency and pedagogical skills. This research employed qualitative method that used document analysis and interviews for data collection. Interviews with principals and teacher educators were used to obtain data and evidence about the beginner teachers' language proficiency and preparedness to teach and document analysis was used to explore the content of the English teacher education curriculum that covers English proficiency and teaching skill related courses. The results showed that school principals did not always perceive the English proficiency and teaching skills of new teachers to be adequate for entering the teaching profession. In contrast, teacher educators gave a view that pre-service teachers who had completed an English teacher education program were equipped with adequate language knowledge, language proficiency, and language teaching skills. This research makes recommendations to improve the quality of this program, in particular, program curriculum content reform for developing language knowledge and language teaching skills.
\end{abstract}

Keywords Knowledge base for language teachers, English proficiency, Teaching skill 


\section{EXTENDED SUMMARY}

To produce high-quality teaching which finally will change student achievement, teachers should know what they should do and how they do it. This issue has attracted several scholars' attention. Shulman and Shulman (2004) described an accomplished teacher as someone able to understand what must be taught and how to teach it. This is what they referred to as the quality of teachers - it is stated in terms of what they know and are able to do. Also, when examining pre-service ESL teacher education programs, the formal institutions that produce English teachers, Day (2012) identified two aspects that can be used as an assessment. The first is the knowledge base for teachers to teach, and the second is the ways that knowledge is delivered to the students. Drawing on Shulman's (1987) pedagogical content knowledge (PCK) framework, Day and Conklin (1992) pointed to four types of the knowledge base for language teachers. First is content knowledge of the subject matter, which refers to the language knowledge that ESL or EFL teachers teach. Second is pedagogic knowledge, which refers to knowledge of generic strategies, or of the ways that teachers teach. Third is PCK, which refers to knowledge of how to present content knowledge in various ways that students can understand, as well as knowledge of what problems they might encounter and how to overcome these. The fourth is support knowledge, which is knowledge of the various disciplines that inform teachers' approaches to teaching and learning English. The aim of this research was to document information on English teacher education program at one state-owned university in Jambi, Indonesia in order to better prepare student teachers with sufficient knowledge and skills they need to teach. Information was gathered from school principals' and teacher educators' perceptions on beginner teachers' English proficiency and pedagogical skills. This research was part of a larger research investigating the effectiveness of English teacher education program in Jambi University, Indonesia. The research was focused on answering the question of how teacher educators and school principals (as employers) perceived Jambi University EFL graduates as beginner teachers toward their English proficiency and teaching skills and to what extend the curriculum contents used in the program accommodated these needs. To document the interaction between the participants, their world (in this case, their English teacher education program and schools) and their experiences, we employed interviews as one method of data collection. The purpose of using interviews was to provide in-depth information about the participants' experiences or viewpoints of a particular topic (Creswell, 2007; Turner, 2010). The school principal participants in this study were selected from the schools in which the first-year English teachers taught. Moreover, in order to gather information regarding the implementation of the English teacher education program curriculum and the program itself, interviews with five teacher educators were conducted.

Additionally, document analysis was used to determine the curriculum content of the English teacher education program at Jambi University. Documents such as the official English teacher education curriculum and policies linked to the Jambi University teacher education program were analysed to gain a comprehensive overview of the program. To analyse the data, thematic analyses (Liamputtong, 2009; Mukminin, 2012; Mukminin \& McMahon, 2013) involving initial coding, axial coding, and selective coding were used to discover appropriate themes from interviews. Also, in this study, the data were analysed using thematic analysis, which involved identifying, analysing and reporting themes in the data. The findings indicated two major themes: (1) stakeholders' perceptions towards beginner teachers' English proficiency and pedagogical skills and (2) the curriculum content of EFL teacher education at Jambi University.

The findings indicated that stakeholders' perceptions on beginner teachers' English proficiency and pedagogical skills indicated that beginner teachers from English teacher education program at Jambi University had adequate language knowledge and proficiency. However, they commented that the pedagogical skills of new beginner teachers should be improved. Also, teacher educators in this study expressed that pre-service teachers who had completed an EFL teacher education program were equipped with adequate language knowledge, language proficiency, and language teaching skills. If later, it was found that they could not demonstrate these things in their teaching, there must be another important reason behind that. They believed the graduates were ready, and that poor teaching was most likely attributable to other school factors.

In terms of the curriculum content of EFL teacher education, the findings from this study indicated that experiential learning how to teach in school settings experienced as student teachers was not always optimum. It might cause a lack expertise in pedagogy areas with graduates and beginner teacher. 
Therefore, the English teacher education program at Jambi University could arrange in-house training for its graduates who are teaching in schools to renew and enhance their teaching skills to meet the demand of high expectations from the teaching profession in EFL contexts nowadays. Also, the findings of this study demonstrated that there was a need to balance courses related to pedagogical skills and courses related to language skills. 


\section{INTRODUCTION}

There has been a considerable amount of studies both internationally and locally investigating the quality of teaching as high quality teaching depends on the competent people who work as teachers at school, (e.g. Lortie, 1975; Kyriacou, Hultgren, \& Stephens, 1999; OECD, 2005; Mukminin, Ali, \& Ashari, 2015). To produce high quality teaching which finally will change student achievement, teachers should know what they should do and how they do it. This issue has attracted several scholars' attention. For example, Shulman and Shulman (2004) described an accomplished teacher as someone able to understand what must be taught and how to teach it. This is what they referred to as the quality of teachers - it is stated in terms of what they know and are able to do. Also, when examining pre-service ESL teacher education programs, the formal institutions that produce English teachers, Day (2012) identified two aspects that can be used as an assessment. The first is the knowledge for teachers to teach, and the second is the ways that knowledge is delivered to the students. Drawing on Shulman's (1987) pedagogical content knowledge (PCK) framework, Day and Conklin (1992) pointed to four types of the knowledge base for language teachers. First is content knowledge of the subject matter, which refers to the language knowledge that ESL or EFL teachers teach. Second is pedagogic knowledge, which refers to knowledge of generic strategies, or of the ways that teachers teach. Third is PCK, which refers to knowledge of how to present content knowledge in various ways that students can understand, as well as knowledge of what problems they might encounter and how to overcome these. The fourth is support knowledge, which is knowledge of the various disciplines that inform teachers' approaches to teaching and learning English.

Further, Richards (2010) proposed the dimensions of teacher knowledge and skill that are at the core of expert teacher competence and performance in language teaching. According to Richards, there are 10 dimensions of teacher knowledge and skill. The first is the language proficiency factor of the teacher. There are several language-specific competencies that a language teacher needs in order to teach effectively, such as the ability to comprehend texts accurately, provide good language models, and maintain use of the target language in the classroom. Richards pointed out that a teacher's level of language proficiency will determine the level of that teacher's confidence; thus, teachers who perceive themselves as weak in the target language will have reduced confidence in their teaching ability. The second dimension is the role of content knowledge. According to Richards (2010), content knowledge is what teachers need to know about what they teach. Similarly, Day and Conklin (1992) stated that content knowledge of the subject matter is the language knowledge that language teachers teach. Content knowledge for language teachers includes what teachers know about language teaching, and constitutes knowledge that would not be shared with teachers in other subject areas. Interestingly, in explaining the role of content knowledge, Richards (2010) proposed what he called disciplinary knowledge and PCK, in his effort to distinguish between theory and practice issues in language teaching. Disciplinary knowledge is a specific body of knowledge considered essential for the language teacher. This knowledge is acquired by special training and is part of a teacher's professional education. It does not translate into practical skills. An example of this is knowledge about second language acquisition and sociolinguistics. In contrast, PCK is the knowledge that provides a basis for language teaching, which can be applied in different ways to resolve practical issues, such as curriculum planning, assessment, reflective teaching and classroom management. While Shulman (1987) defined PCK as teachers' understanding of what should be learnt and how it should be taught, Freeman (2009) added that teachers should have mastery of the content to teach and the methodologies to teach it. The third dimension of teacher knowledge is teaching skills. Richards (2010) stated that teacher training involves developing a great number of teaching skills. These skills can be obtained by observing experienced teachers, and often by having practice teaching in a controlled setting, using activities such as microteaching and peer teaching. Richards further explained that having opportunities to experience teaching in various situations with different kinds of learners, and teaching different kinds of content, is how a repertoire of basic teaching skills is acquired.

Additionally, the fourth dimension of knowledge required by language teachers is contextual knowledge (Richards, 2010). Given that teachers teach in many different contexts, in order to function in those contexts, they must acquire appropriate contextual knowledge that will enable them to learn to be effective in different countries, backgrounds and cultures. Richards (2010) further explained that optimum teacher learning occurs through classroom experiences, in which the relationships among teacher educators, fellow novice teachers, and experienced teachers are maintained in schools. Learning 
to teach in a specific context is a process of socialisation that involves becoming familiar with a professional culture and its goals while sharing values and norms of conduct. This 'hidden curriculum' of professional socialisation is often more powerful than the school's prescribed curriculum. The fifth dimension is language teacher identity. According to Richards (2010), this dimension goes beyond skills and knowledge to developing an understanding of what it means to be a language teacher. That is, it refers to an identity that is shaped and reshaped as the student teacher takes on the roles and responsibilities of a classroom teacher. The sixth dimension is the learner-focused teaching dimension. Regarding this, Richards (2010) explained that teaching is a 'performance', whereby the teacher takes account of both the social and learning interests of students, building a community of learners in the classroom. This is undertaken by managing the learning environment, with the aim of creating a pleasant and productive setting. The seventh dimension proposed by Richards (2010) for language teachers is pedagogical reasoning skills. An important component in the current conceptualisation of SLTE is the focus on teacher cognition. Pedagogical reasoning takes account of the ways in which teachers' beliefs and cognitive processes shape their thinking and actions in relation to classroom practice. The eight dimension identified by Richards (2010) is the 'theorising of practice'. This refers to the ways personal understandings and knowledge (theories) are shaped (at least partly) by practical experience of teaching. This helps make sense of experience and informs classroom practice. This dimension is different from the application of theory, which involves connecting concepts, information and theories with practice (Richards, 2010). Rather, theorising of practice involves reflection on one's teaching practice in a variety of ways, and theorising about the effect of that practice on learners. This can lead to changes in practice and the implementation of subsequent actions based on this theorising. The ninth dimension of teacher knowledge and skill proposed by Richards (2010) is membership in a community practice. This dimension is about collaboration and sharing knowledge between professionals - in this case, language teachers. This can lead to enhanced practices through teamwork and group collaboration. According to Richards and Farrel (2005), membership in a community of practice provides teachers the opportunity to work and learn together in activities with shared goals and responsibilities, including teacher trainers, mentors and team leaders. The final dimension of teacher knowledge and skill is professionalism. According to Richards (2010):

"English language teaching is not something that anyone who can speak English can do. It is a profession, which means that English teaching is seen as a career in a field of educational specialization, it requires a specialized knowledge base obtained through both academic study and practical experience, and it is a field of work where membership is based on entry requirements and standards" (p. 119).

Richards (2010) further stated that:

"Becoming an English language teacher means becoming part of a worldwide community of professionals with shared goals, values, discourses, and practices but one with a self-critical view of its own practices and a commitment to a transformative approach to its own role" (p. 19).

Similarly, Faez (2011) advocated four domains of the knowledge base for second language teachers: content knowledge, pedagogic knowledge, PCK and support knowledge. These domains were designed for EFL or ESL teacher education programs in Canada. Faez (2011) also pointed out that content knowledge of language teachers encompasses knowledge of English as the subject being taught, while pedagogic knowledge is teaching practice knowledge. According to Faez (2011), PCK refers to teaching strategies possessed by teachers to deliver English to students, while knowledge in the area of linguistics is categorised as teachers' support knowledge. Faez stated that teaching skills are essential and a core competency required by teachers. His view on language teacher education, teaching skills include the ability to develop competence using language teaching methods and strategies. It also includes the ability to adapt teaching skills and approaches to new situations. He stated that teacher education programs have a significant role in preparing teachers to develop these appropriate teaching skills.

Another competency that must be possessed by language teachers is communication skills and language proficiency. Developing effective communication skills as a basis for language teachers is important to support effective language teaching. It is essential for teachers to have advanced proficiency in the target language, and the ability to use it as a medium of instruction. However, language proficiency can be an issue for English teachers with a non-native background; with this being their most commonly identified weakness (Luciana, 2006). Faez (2011) also highlighted that teachers' lack of confidence in language proficiency may limit their ability to conduct classroom functions through the medium of the target language. Thus, the language proficiency of teachers is a factor that may affect major aspects of their 
teaching expertise, including a demonstration of teaching skills and subject matter knowledge (Richards, 2010). Faez (2011) defined subject matter knowledge as the characteristics of language and its usage. This includes understanding phonology, syntax, and the aspects of second language learning. Knowledge of the subject matter also encompasses understanding the principles of language teaching, developing curriculum and learning materials, and undertaking assessment and evaluation techniques. In a discussion of teachers' pedagogical skills and decision making, Faez suggested that language teachers must be able to identify pedagogical issues that may arise, and be able to adjust or adapt their teaching approach as needed so that the goals of teaching can be achieved. Teachers' ability to link theories about language, learning and teaching with their actual practice is also part of teachers' pedagogical reasoning and decision-making (Richards, 1998, 2010). In preparing lessons in the classroom, teachers need to acquire and apply generic teaching skills. According to Moore (2007), there are three generic teaching skills applicable for all teachers at all levels: pre-instructional skills, instructional skills, and post-instructional skills. Pre-instructional skills include planning the lesson, which encompasses writing the lesson goals, selecting learning materials, and structuring the lesson to meet the learning styles of the students. Instructional skills are those applied to implementing the planning in practice, while post-instructional are the skills needed to be an evaluator to assess students' performance and mastery.

Among dimensions about what English teachers should know and be able to do as proposed by Richards (2010), this research focused only on language proficiency and language teaching skill dimensions. Therefore, the research was focused on the beginner teachers' English proficiency and teaching skills perceived by school principals and teacher educators. The results of this research are expected to be useful information for Jambi University in improving the quality of its English teacher education by redesigning the curriculum content that best meet the demand of qualified English teachers to work with students in school settings. This research was part of a larger research investigating the effectiveness of English teacher education program in Jambi University, Indonesia. The research was focused on answering questions of how teacher educators and school principals (as employers) perceived Jambi University EFL graduates as beginner teachers toward their English proficiency and teaching skills and to what extend the curriculum contents used in the program accommodated these needs. English proficiency dimension in this study refers to what Richards (2010) defines as the ability that language teachers should have in order to teach effectively, such as the ability to comprehend texts accurately, provide good language models, and maintain use of the target language in the classroom. Whereas, the language teaching skill refers to the ability to deliver language content to students such as the ability to teach in various situations with different kinds of learners, use appropriate strategies, and teaching different kinds of content.

\section{METHOD}

\section{Design}

In this research, in order to determine the interaction between the participants, their world (in this case, their English teacher education program and schools) and their experiences, we employed interviews as one method of data collection. The purpose of using interviews was to provide in-depth information about the participants' experiences or viewpoints of a particular topic (Creswell, 2007; Turner, 2010). The school principal participants in this study were selected from the schools in which the first-year English teachers taught. The selection criteria for school principal participants involved in this study that they were English teachers so that they have related knowledge and experience that would be helpful and a good source of data for the purpose of the study. Moreover, in order to gather information regarding the implementation of the English teacher education program curriculum and the program itself, interviews with five teacher educators were conducted. The selection of teacher educator participants participating in this study was based on the idea that they are the designer as well as the user of English as a Foreign Language Teacher Education Program (EFLTEP) Curriculum. Thus, they have worked with and implemented the curriculum for a period of time. Teacher educators were considered a good source of knowledge for seeking the information regarding the implementation of EFLTEP's curriculum and any issues about the program. 
Table1. Group of Participants

\begin{tabular}{lll}
\hline \multicolumn{1}{c}{ Categories of Participants } & \multicolumn{1}{c}{ Criteria } & \multicolumn{1}{c}{ Information } \\
\hline $\begin{array}{l}\text { School principals (five } \\
\text { interviews) }\end{array}$ & $\begin{array}{l}\text { School principals who were selected } \\
\text { from the schools in which the first- } \\
\text { year English teachers taught }\end{array}$ & $\begin{array}{l}\text { English teachers' readiness and } \\
\text { preparedness to teach in the classroom } \\
\text { Implementation of the English as a }\end{array}$ \\
$\begin{array}{l}\text { Teacher educators (five } \\
\text { interviews) }\end{array}$ & $\begin{array}{l}\text { English teacher education program } \\
\text { staff who were teaching the student } \\
\text { teachers }\end{array}$ & $\begin{array}{l}\text { Foreign Language Teacher Education } \\
\text { Program EFLTEP curriculum, and any } \\
\text { issues regarding the program }\end{array}$ \\
\hline
\end{tabular}

This study did not aim to use statistics to test any specific hypothesis but focused on exploring the participants' perspectives and opinions. The choice of interview participants in this study was based on their background in order to meet the purpose of this study, and to align with the literature underpinning the study (Creswell, 2007; Merriam, 1998; Cohen et al., 2011). Non-probability sampling was considered for this study because "the research process is one of "discovery" rather than the testing of hypotheses' (Denscombe, 2007, p. 29). In addition, May and Cantley (2001) pointed out that, in some cases, the criterion of 'fit for purpose' (p. 95) is more important than the statistical accuracy of probability sampling. In addition, according to Cohen et al. (2011), non-probability samples are frequently used in small-scale research, such as with one or two schools, and two or three groups of students or teachers.

Document analysis is a technique for evaluating documents, both as printed and electronic material (Creswell, 2007; Merriam, 1998; Bowen, 2009). The purpose of employing document analysis in this research was to obtain meaning and understanding and develop empirical knowledge (Corbin \& Strauss, 2008). Document analysis was used to determine the curriculum content of the English teacher education program at Jambi University. Documents such as the official English teacher education curriculum and policies linked to the Jambi University teacher education program were analysed to gain a comprehensive overview of the program. This method of document analysis was an attempt to attain supplementary research data that might be helpful to support the core data gathered from the interviews. As Bowen (2009) stated, documents can provide valuable information and insights for supplementary data during research, and can be used as a means of tracking the change and development of a program or event.

This study's questions were about the participants' experiences and perceptions of the program, feelings about the program, expectations of the program, and beliefs about what changes need to be made to the program. These are typical questions featured during evaluation interviews. Patton (2002) further explained that the interviewer needed to provide a framework within which the participants can respond comfortably, accurately and honestly to these kinds of questions.

At the time that the potential participants were approached to take part in the interview, they were provided with a plain language statement and consent form in accordance to Human Research Ethics at RMIT University. Five school principals and five teacher educators who indicated interest in being interviewed were approached. The principal participants were selected from the schools at which the five interviewed beginner teachers taught. All interviews were conducted at a time nominated by the interviewees. The interviews were conducted in Indonesian, which was transcribed and then translated into English by a third party. Each interview lasted approximately 30 minutes and was audio recorded. For the purpose of privacy, the identity of the participants was protected by not recording names, and then coding the participants as Participant 1, Participant 2 and so forth.

The aim of data analysis is to create meanings from raw data (Johnson \& Christensen, 2008; Mukminin, 2012). Simons (2009) stated that analysis involved a process such as 'coding, categorizing, concept mapping, theme generation - which enable you to organize and make sense of the data in order to produce findings and an overall understanding (or theory) of the case' (p. 116). In line with Johnson and Christensen (2008) and Simons (2009), Creswell (2009) asserted that analysis:

"involves preparing data for analysis, moving deeper and deeper into understanding the data (some qualitative researchers use the metaphor of peeling back the layers of an onion), representing the data, and making an interpretation of the larger meaning of the data" (p. 183).

There are a variety of ways to use thematic analysis for qualitative data. According to Liamputtong (2009), thematic analysis involves initial coding, axial coding and selective coding, which is aimed at discovering appropriate themes from interviews. In this study, the data were analysed using thematic 
analysis, which involved identifying, analysing and reporting themes in the data. In addition, Creswell (2009) suggested six steps to analyse data collected from interviews: (i) organising and preparing the data for analysis; (ii) reading through all the data; (iii) beginning detailed analysis with a coding process; (iv) using the coding to generate a description of the setting or people, and create categories or themes for analysis; (v) advancing how the description and themes will be represented in the qualitative narrative; and (vi) interpreting or finding meaning from the data.

The process of thematic analysis in this study adopted the steps suggested by Creswell (2009) and Liamputtong (2009). The interview recordings were transcribed by the researcher and manually analysed for key themes. Data obtained from the curriculum documents. The data from document analysis and interview transcriptions were read repeatedly to assist this process. The data were summarised and grouped with codes, then organised into categories. Other related documents and interview transcriptions were read repeatedly to assist this process. The data were summarised and grouped with codes, then organised into categories, such as student teachers' pedagogic knowledge, resourcing, teacher educators' role, communication between teacher educators and supervising teachers during teaching practice, the need for curriculum change, and possible solutions. These categories were further evaluated to identify new connections, which revealed the key themes. These themes are described and presented in the findings part. The key themes were used to address the research questions by linking the data and theoretical frameworks to draw conclusions.

\section{Trustworthiness}

To guarantee the credibility of our study or the "trustworthiness" (Lincoln \& Guba 1985, p. 300) of our study, we conducted individual interviews and to validate the accuracy of the data, findings, and interpretations (Creswell, 2007; Johnson \& Christensen, 2008). We checked not only with the participants but also with our colleague that served as member checking. Our colleague graduated from a Ph.D. program in the United States of America who had taken three qualitative research methods during his Ph.D. program. He was also a qualitative research assistant during his Ph.D. program and his dissertation was purely qualitative. Additionally, he already published his research articles in peerreviewed journals indexed in Scopus and ISI Thomson. We also returned the transcribed interview data, findings, and final report to each participant. This approached was chosen to ensure that each participant agreed with the data that we used from them.

\section{FINDINGS and DISCUSSION}

The purpose of this inquiry was to document information on English teacher education program at one state-owned university in Jambi, Indonesia in order to better prepare student teachers with sufficient knowledge and skills they need to teach. This research was part of a larger research investigating the effectiveness of English teacher education program in Jambi University, Indonesia. The research was focused on answering questions of how teacher educators and school principals (as employers) perceived Jambi University EFL graduates as beginner teachers toward their English proficiency and teaching skills and to what extend the curriculum contents used in the program accommodated these needs. The findings of this study were categorized into two main themes as presented below.

\section{Stakeholders' perceptions towards student teachers' English proficiency and pedagogical skills}

Data for stakeholders' perceptions on beginner teachers' English proficiency and pedagogical skills were obtained from interviews. Four out of five school principals who participated in the interviews agreed that the beginner teachers from English teacher education program at Jambi University had adequate language knowledge and proficiency. However, they commented that the pedagogical skills of new beginner teachers should be improved. As School Principal (1) said,

"I think Mr N is good at speaking as I have seen him teaching English to students by using English for instruction in the classroom. But for his ability to manage students to engage in learning process, this needs to be improved."

In addition to that, school principal (2) mentioned that beginner teacher from Jambi University has demonstrated a good level of English but he (the teacher) still needed more practical experiences in terms of classroom management and teaching skills. 
This observation about beginner teachers was supported by other studies conducted by Luciana (2006) and Abednia (2012) who suggested that while language teachers may have a good level of proficiency in the language they teach, they also need to be able to demonstrate skills to transfer this proficiency to their students. Data from interviews with school principals revealed that limited experience is the most likely factor that causes beginner teachers to show a lack of strategies in coping with their tasks. beginner teachers from Jambi University tended to agree as they perceived their inadequate knowledge of pedagogy came mostly through lack of experience. As School Principal (3) said: 'I have mostly found EFL beginner teachers from Jambi University who teach in this school to have less knowledge of pedagogy. This may be caused by lack of experience'.

Moreover, school principal (4) perceived that both language proficiency and teaching skills of new teachers need to be improved by encouraging them to join professional training and other in -service trainings which are carried out by local Ministry of National education. As he mentioned,

Mr A has taught English in this school for nearly two years and I always encourage him to join any professional training that can improve his language knowledge and teaching skills. Not only English teachers but also other teachers in this school are encouraged to join such training.

Unlike, her colleagues, School Principal (5) believed that a new English teacher in her school has shown a good level of English as well as the pedagogical skills. She said, "Ms D has demonstrated a good level of both English and the teaching skills. The students like the way Ms D teaching them, it is engaging and interesting. Now, many students can speak English."

In contrast, teacher educators gave a view in the interviews that pre-service teachers who had completed an EFL teacher education program were equipped with adequate language knowledge, language proficiency, and language teaching skills. If later, it was found that they could not demonstrate these things in their teaching, there must be another important reason behind that. They believed the graduates were ready, and that poor teaching was most likely attributable to other school factors. Teacher Educator (1) stated,

"Pre-service teachers who have completed their EFL teacher education program have been equipped with adequate language knowledge and language teaching skills. If later we found that they could not perform well in their teaching profession, there must be a reason of sorts behind that."

In line with teacher educator (1), teacher educator (2) mentioned that English teacher education graduates have been equipped with adequate language proficiency and teaching skills they need to teach. However, their level of mastery on each skill depends on the individual ability that varies from one to another.

Moreover, teacher educator (3) stated that the graduates of the EFL teacher education program Jambi University had good speaking and reading skills, but lower proficiency in writing and listening:

"If we are talking about English skills of our graduates, for speaking and reading skills, I think they are good at this. They use English for communication in classrooms with their colleagues. Reading is a skill that our graduates are good at. As I teach speaking and reading courses to EFL student teachers, I know their proficiency on those two skills. However, their proficiency in writing and listening skills is not sufficient."

In line with the previous comments from the teacher educators, Teacher Educator (5) perceived that the English teacher education program's graduates have been well prepared with the language knowledge and language teaching skills they need to teach English. However, she stated that, to be professional in teaching, graduates must be encouraged to upgrade and update their knowledge through the various programs initiated by the Indonesian government, such as the Teacher Professional Development Program, which is currently popular among teachers throughout Indonesia. She stated,

"As teacher educators, we have to prepare our student teachers with the knowledge and skills they need to be English teachers. This quality outcome is written into our curriculum. EFLTEP graduates must have pedagogical competence, subject matter content knowledge, personal and social competence. They also need to continue learning as a teacher to upgrade their knowledge to keep up with education needs in the future".

The perceptions of the teacher educators suggested that there was a need for improving English language proficiency among the student teachers, and that they need pedagogy knowledge on how to teach students who learn EFL. The findings of this study demonstrate that there is a need to balance subjects related to pedagogical skills and subjects related to language skills. The interview data with teacher educators implied a belief that the core of knowledge base delivered to EFL student teachers equips and 
prepares them to be ready to teach English. However, in order to expand and build upon this initial knowledge base, assembled while being student teachers, there is a crucial need to provide them with an in-service program to keep them with updated after they enter teaching profession in the future.

\section{The Curriculum Content of EFL Teacher Education}

As mentioned earlier, English teacher education programs need to include what teachers should know and be able to do in their curriculum contents. In other words, the aspects of language proficiency and teaching skills should be the core content of the program curriculum. In line with that notion, in assessing to what extend an English teacher education program has effectively provided its student teachers with knowledge and skills to teach, Day (2012) proposed two aspects that can be used as assessment. The first is the knowledge base for teachers to teach, and the second is the ways that knowledge is delivered to the student teachers. It is a matter of teaching student teachers learning how to teach.

Richards' (2010) framework of ten dimensions of teacher knowledge and skills was used as a guideline for analysing English teacher education curriculum in this research. According to Richards (2010), language proficiency is the first dimension that language student teachers must acquire. This refers to the language-specific competencies that language teachers require in order to teach effectively, such as the ability to comprehend the texts accurately, provide good language models, and use the target language for instruction in the classroom. Courses related to language proficiency in the English teacher education program in Jambi University curriculum include Listening (one to four), Speaking (one to four), Reading (one to four), Writing (one to four), Interpreting, English Grammar (one to four), Vocabulary (one to two), Pronunciation and Translation. These courses fall under the category of English skills and language elements. The total credit points of these courses add to 49 credit points or $32 \%$ of the total 150 compulsory credit points offered in the program. The following table shows how the course lists are categorised for language proficiency.

Table 2. Language Proficiency Courses

\begin{tabular}{lcc}
\hline Course Title & Semester Offered & Total Credit Points \\
\hline Listening & 1 to 4 & 8 \\
Speaking & 1 to 4 & 8 \\
Reading & 1 to 4 & 8 \\
Writing & 1 to 4 & 8 \\
Grammar & 1 to 4 & 9 \\
Vocabulary & 2 to 3 & 4 \\
Pronunciation & 2 & 2 \\
Translation & 2 & 2 \\
Total & & $49(32 \%)$ \\
\hline
\end{tabular}

Teaching skills is another important dimension proposed by Richards (2010). Teacher education or teacher training programs are the places for developing a great number of teaching skills. According to Richards (2010), examples of teaching skills include selecting learning activities, preparing students for new learning, monitoring students' learning, giving feedback on students' learning and so forth. Courses such as Teaching English as a Foreign Language, Teaching English for Young Learners, and Teaching Practicum Project are examples of the teaching skills dimension covered in the English teacher education program in Jambi University curriculum. This covers about $8 \%$ of the total credits offered during the program. The following table lists the teaching skill courses.

Table 3: Teaching Skill Courses

\begin{tabular}{lcc}
\hline Course Title & Semester Offered & Total Credit Points \\
\hline Teaching English as a Foreign Language (theory) & 5 & 2 \\
Teaching English as a Foreign Language (practice) & 6 & 4 \\
Teaching English for Young Learners (elective) & 6 & 2 \\
Teaching Practicum Project & 7 & 4 \\
Total & & $12(8 \%)$ \\
\hline
\end{tabular}

Based on table 2 and table 3, it shows that language proficiency and language teaching skill related courses cover $40 \%$ (32\% and $8 \%$ ) of the total credit points offered in the program. Other dimensions of language teacher knowledge and skills proposed by Richards (2010) such as content knowledge, 
contextual knowledge, teaching skills, professionalism, membership of community practice, pedagogical reasoning skills, and learner-focused teaching, cover the rest of the total credit points which is $60 \%$.

It can be seen from the content analysis of the English curriculum used in EFL teacher education program of Jambi University that courses related to language proficiency has covered $32 \%$ of the total credit points. This portion is accordance with the fact that 4 out of 5 school principals have perceived that Jambi University graduates of English education have been well equipped with language proficiency they need to teach. By having more English courses, it will provide more opportunity for student teachers to enhance their language skills. Beside the quantity of English language related courses, the quality of each course also need to be improved as indicated by Teacher Educator (3) that student teachers have less proficiency in Writing and Listening skills compared to Speaking and reading skills. The delivery of these Writing and Listening courses need to be improved as well as the learning sources that support them.

Regarding the language teaching skill courses, the portion of courses related to pedagogical skills is considered not adequate compared to other courses which is only $8 \%$ of the total courses offered in the program. This brings impact that the beginner teachers form Jambi University who have been teaching in several schools in Jambi Province have less adequate pedagogical skills. This weakness is also mentioned by school principals participating in this study. All school principal participants agreed that new English teachers teaching in their schools need to improve their teaching skills in order to be able to engage students in the teaching and learning process. So, the need for more pedagogical skill related courses is highly recommended to accommodate student teachers' need for better knowledge of language teaching.

\section{CONCLUSION}

Elaborating on the views from school principals and teacher educators, and the curriculum content of English teacher education in Jambi, it is clear that English beginner teachers do need to continue to develop professionally in response to ongoing changes in the field of EFL teaching (Rahayu \& Hizriani, 2014; Irmawati, 2014). As pointed out by Richards (2001), teachers need regular opportunities to update their professional knowledge and skills through typical activities such as attending conferences, undertaking workshops and in-service seminars, and establishing reading groups. In line with previous comments from teacher educators, one teacher educator (Teacher Educator 1) pointed out that Jambi University's graduates have been well prepared with the language knowledge and EFL teaching skills needed to teach English but she also believed that to be fully professional in teaching, graduates are to be encouraged to upgrade and update their knowledge through programs initiated by Indonesian Government such as the Teacher Professional Development Program that is currently popular with teachers in Indonesia.

The need for teacher professional development is essential to the strengthening of the position of English as a foreign language in Indonesia. According to Irmawati (2014), in the context of EFL teachers, Teacher Professional Development (TPD) refers to that process in which the teachers can increase their English skills as well as knowledge of English content that they teach. A study investigating teacher professional development in South Kalimantan (Indonesia) conducted by Rahayu and Hizriani (2014) found that in terms of ongoing development, the English teachers involved in her study did several activities to enhance their professional expertise, such as: personal reflection and collaborative discussion with colleagues. There are other kinds of activities that teachers can employ to develop their teaching skills, such as peer observation, student feedback, and engagement with reading materials related to English teaching.

The findings from this study indicated that experiential learning how to teach in school settings experienced as student teachers was not always optimum. It might cause a lack expertise in pedagogy areas with graduates and beginner teacher. Therefore, the English teacher education program at Jambi University could arrange in-house training for its graduates who are teaching in schools to renew and enhance their teaching skills to meet the demand of high expectations from the teaching profession in EFL contexts nowadays.

Regarding the curriculum content of the program, the findings of this study demonstrated that there was a need to balance courses related to pedagogical skills and courses related to language skills. Based on 
the data, there was a significant proportional gap between language skill courses (32\%) and pedagogical skill courses (8\%). In order to prepare English teachers with adequate knowledge and skills-what should be learnt by students and how teachers should be taught it to students--the program must balance both language skill-related subjects (such as speaking, writing, reading and listening skills) and pedagogical skill-related subjects (such as the Teaching English as Foreign Language Strategy and Practice Course, curriculum and material development subjects, and teaching practicum). The data from the interviews show that improving these skills among new teachers must remain a focus in the future. These findings align with other research conducted in teacher education, especially in language teacher education in Indonesia, which has suggested that there is a crucial need for teacher education to prepare graduates with adequate levels of English language proficiency and pedagogical skills to be fully competent professional teachers of English (Luciana, 2006; Rahayu \& Hizriani, 2014).

\section{REFERENCES}

Abednia, A. (2012). Teachers' professional identity: Contribution of a critical EFL teacher education course in Iran. Teaching and Teacher Education, 28(5), 706-717.

Bowen, G. A. (2009). Document analysis as a qualitative research method. Qualitative Research Journal, 9(2).

Creswell, J. W. (2009). Research design: Qualitative, quantitative, and mixed methods approaches (3rd ed.). California: Sage Publication.

Creswell, J. W. (2007). Qualitative inquiry and research design: Choosing among five traditions. Thousand Oaks, CA: Sage Publications, Inc.

Cohen, L., Manion, L. \& Morrison, K. (2011). Research methods in education (7th ed.). New York, NY: Routledge.

Corbin, J. M. \& Strauss, A. L. (2008). Basic of qualitative research: Techniques and procedures for developing grounded theory (3rd ed.). Los Angeles, CA: Sage

Day, R. (2012). Models and the knowledge base of second language teacher education. University of Hawaii Working Papers in ESL, 11(2), 1-13.

Day, R. R. \& Conklin, G. (1992). The knowledge base in ESL/EFL teacher education. Paper presented at the TESOL Conference.

Denscombe, M. (2007). The good research guide for small-scale social research projects. New York, NY: Open University Press.

Faez, F. (2011). Points of departure: Developing the knowledge base of ESL and FSL teachers for K-12 programs in Canada. The Canadian Journal of Applied Linguistics, 14(1), 48-82.

Freeman, D. (2009). The scope of second language teacher education. In A. Burns \& J. C. Richards (Eds.), The Cambridge guide to language teacher education (pp. 11-19). New York, NY: Cambridge University Press.

Irmawati, D. K. (2014). Models of TEFL teachers' professional development. Paper presented at the TEFLIN International Conference, Solo, Indonesia.

Johnson, B., \& Christensen, L. B. (2008). Educational research: Quantitative, qualitative, and mixed approaches ( $3^{\text {rd }}$ ed.). Boston: Sage Publications, Inc.

Kyriacou, C., Hulthgren, A., \& Stephens, P. (1999). Student teachers' motivation to become a secondary school teacher in England and Norway. Teacher Development, 3 (3), 373-381.

Liamputtong, P. (2009). Qualitative data analysis: Conceptual and practical considerations. Health Promotion Journal of Australia, 20(2), 133-139.

Lortie, D. C. (1975). Schoolteacher: A sociological study. London: The University of Chicago Press.

Luciana. (2006). Developing standards for language teacher education programs in Indonesia: Professionalizing or losing in complexity. TEFLIN Journal, 7(1), 19-28.

May, T. \& Cantley, C. (2001). Social research: Issues, methods, and process (3rd ed.). Buckingham, England: Open University Press.

Moore, K. D. (2007). Classroom teaching skills. Boston, MA: McGraw-Hill.

Mukminin. A. (2012). Acculturative experiences among Indonesian graduate students in US higher education: academic shock, adjustment, crisis, and resolution. Excellence in Higher Education Journal, 3 (1), 14-36.

Mukminin, A., \& McMahon, B.J. (2013). International Graduate Students' Cross-Cultural Academic Engagement: Stories of Indonesian Doctoral Students on American Campus. The Qualitative Report, 18 (69), 1-19.

Mukminin, A., Ali, R. M., \& Ashari, M. J. (2015). Voices from Within: Student Teachers' Experiences in English Academic Writing Socialization at One Indonesian Teacher Training Program. The Qualitative Report, 20(9), 1394-1407. Retrieved from http://nsuworks.nova.edu/tqr/vol20/iss9/2

Organisation for Economic Co-operation and Development. (2005). Teachers matter: Attracting, developing, retaining effective teachers. Paris: OECD Publishing.

Patton, M. Q. (1990). Qualitative evaluation and research methods. Newbury Park, CA: Sage Publications. 
SULISTIYO, MUKMININ, YANTO; In the Spirit of Quality Student Teachers' English Proficiency and Pedagogical Skills Teacher Educators and School Principals' Perception

Rahayu, P. S. \& Hizriani, N. (2014). English teachers' professional development at Hulu Sungai Selatan. South Kalimantan. Paper presented at the TEFLIN International Conference, Solo, Indonesia.

Richards, J. C. (1998). Beyond training: Perspectives on language teacher education. Cambridge, England: Cambridge University Press.

Richards, J. C. (2001). Curriculum development in language teaching. Cambridge, UK: Cambridge University Press.

Richards, J. C. (2010). Competence and performance in language teaching. RELC Journal, 41(2).

Shulman, L. (1987). Knowledge and teaching: Foundations of the new reform. Harvard Educational Review, 57(1), 1-22.

Shulman, L. S. \& Shulman, J. H. (2004). How and what teachers learn: A shifting perspective. Journal of Curriculum Studies, 36(2), 257-271.

Simons, H. (2009). Case study research in practice. London, England: Sage Publications

Turner, D.W. (2010). Qualitative interview design: a practical guide for novice investigators. The Qualitative Report, 15(3), 754-760. 